Int. J. Odontostomat., 9(3):489-492, 2015.

\title{
Accuracy of Resonance Frequency Analysis by Third Generation Osstell ${ }^{\circledR}$
}

\author{
Precisión del Análisis de Frecuencia de Resonancia \\ Mediante Osstell ${ }^{\circledR}$ de Tercera Generación
}

\begin{abstract}
Aritza Brizuela-Velasco*; Felipe J. Fernández-González*; Nerea Martín-Blanco*; David Chávarri-Prado*; Yelko Chento-Valiente $^{\star \star * *}$; Borja Dehesa-Ibarra ${ }^{* * * *}$ \& José Antonio Vega ${ }^{* \star * k *}$
\end{abstract}

BRIZUELA-VELASCO, A.; FERNÁNDEZ-GONZÁLEZ, F. J.; MARTÍN-BLANCO, N.; CHÁVARRI-PRADO, D.; CHENTO-VALIENTE, Y.; DEHESA-IBARRA, B. \& VEGA, J. A. Accuracy of resonance frequency analysis by third generation Osstell ${ }^{\circledR}$ Int. J. Odontostomat., 9(3):489-492, 2015.

ABSTRACT: The Resonance Frequency Analysis by Osstell ${ }^{\circledR}$ is used in the assessment of primary and secondary implant stability. The aim of this study was to determine its accuracy as a method of testing, checking its repeatability and reproducibility. A pilot study was performed whereby implants were placed in a cow rib to compare several ISQ measurements with the same SmartPeg transducer (repeatability), or with different SmartPegs (reproducibility). Statistical analysis of the data showed a high correlation of the ISQ values obtained in both assays, which suggests that Osstell ${ }^{\circledR}$ analysis can provide high repeatability and reproducibility.

KEY WORDS: Osstell, resonance frequency analysis, implant stability, repeatability and reproducibility.

\section{INTRODUCTION}

Implant stability, defined as the control of micromovements at the bone-implant interface, is a key factor for the achievement and maintenance of osseointegration (Gapski et al., 2003). The Resonance frequency analysis (RFA) by Osstell ${ }^{\circledR}$ measures the oscillation frequency of the implant into the bone. The values given, in units of implant stability quotient (ISQ), express the rigidity of the connection between the bone and the implant and have an inverse correlation with micromovements (Pagliani et al., 2013). Dynamic monitoring of an implant ISQ value in the process of osseointegration could facilitate decisions about the surgical procedure and its load, which is particularly useful in immediate loading protocols.

The aim of this study was to determine the accuracy of Osstell ${ }^{\circledR}$ as a test method, analyzing the repeatability and reproducibility of the measurements.

\section{MATERIAL AND METHOD}

Two fresh cow ribs, destined for human consumption were selected, prepared and stored in accordance with the protocol of Tricio et al. (1995). First the ribs were cleaned of all soft tissue residues and were immediately immersed in 50\% ethanol/saline solution, which causes less than a $2 \%$ decline in Young's modulus of bone tissue for up to 90 days. The tests were performed within the first 5 days. Because bone specimens were preserved in ethanol solution lost some residual water, the samples were allowed to soak in iso-osmotic saline for $12 \mathrm{~h}$ before testing and during this period were refrigerated. The bone samples were allowed to stand at room temperature $\left(23^{\circ} \mathrm{C}\right)$ for 3 just before testing.

Once ribs were ready, three and two implants (Klockner Essential Cone ${ }^{\odot}$ ), $4 \mathrm{~mm}$ in diameter and $10 \mathrm{~mm}$ in length with an internal connection were placed

Professor of the Graduate of Oral Implantology, School of Medicine and Dentistry, University of Basque Country, Leioa, Spain.

* Professor of the Graduate of Orthodontics and Dentofacial Orthopedics, Department of Orthodontics, Dentistry School, University of Oviedo, Asturias, Spain.

*** Post-graduate student, Biomedical Research Department of Physiology and Cellular Biology, Department of Medicine, University of the Basque Country, Leioa, Spain.

Post-graduate student, Engineering Physics Department of Nuclear Engineering and Fluid Mechanics, Engineery School, University of the Basque Country, Bilbao, Spain.

Professor of the Graduate of Periodontology and Oral Implantology, Department of surgery, University of Zaragoza, Huesca, Spain.

Full Professor and chair department of Morphology and Cell Biology department. Oviedo University, Asturias, Spain 
respectively on each rib (Fig. 1), using the drilling protocol proposed by the manufacturer (Klockner Implant System, Barcelona, Spain). In order to ensure that all measurements were taken in the same position and at the same angle, a jig was used to avoid any influence of the operator in measurement results (Fig. 2). A first test was then performed to analyze the reproducibility of the measurements taken with the third generation Osstell ${ }^{\circledR}$. The primary stability of the implants expressed in ISQ was measured with five different transducers (SmartPegs) on each implant. The second

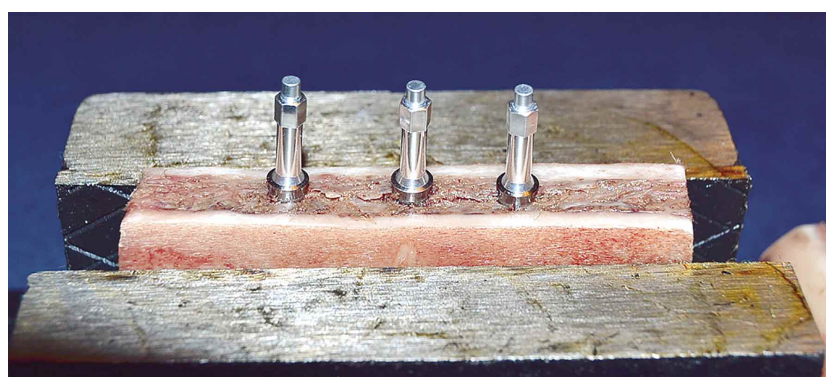

Fig. 1.Three Implant Klockner Essential Cone@ $\odot$ details and its respectively SmartPegs placed on a fresh cow rib.

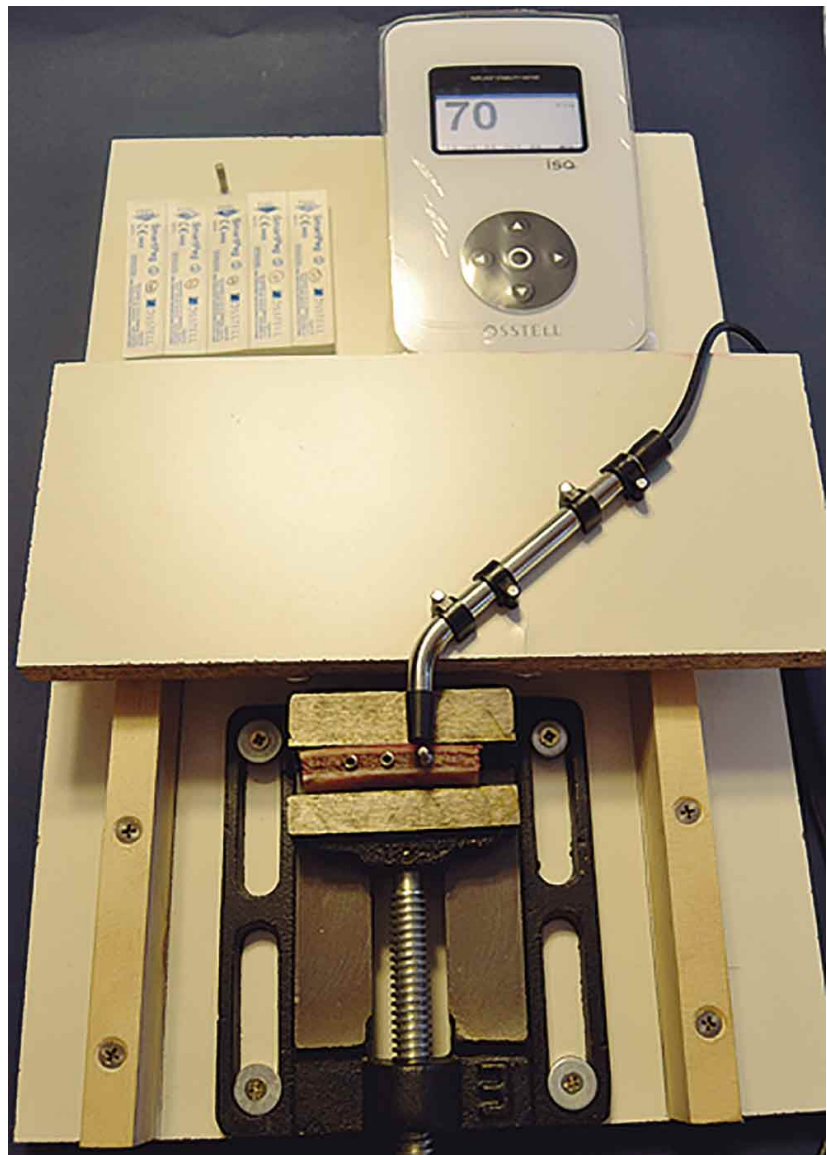

Fig. 2.Positioning of the measuring instrument to avoid the influence of the operator. test was performed to analyze the repeatability, with a Smartpeg assigned to each implant, and 20 consecutive ISQ values were measured by screwing and unscrewing the SmartPegs in each test, using for this purpose the appropriate screwdriver applying a manual torque, according to the manufacturer's instructions (Osstell, Gothenburg, Sweden) and as is done in clinical application. Photographs of SmartPeg thread groups, both those tested and also a control group, were taken using an optical microscope. Once all measurements were performed, the statistical analysis of the results was carried out (desriptive statistic and Anova test).

\section{RESULTS}

The Anova Test of the reproducibility results showed no significant differences between the performed measurements of the five SmartPegs of each implant $(P<0.01 ;$ Fig. 3$)$. The standard deviations of the measurements of different implants were in a range between 0 and 0.71 . Therefore, it may be considered that on a device whose measurements are given in exact values, the dispersion of the ISQ taken from the average value is small.

Regarding the repeatability test, the 20 measurements carried out with a SmartPeg for each of the five implants are shown in Table I. Standard deviations of between 0 and $1.37(95 \% \mathrm{Cl})$ were observed. In the SmartPegs that showed results with more deviation when comparing the means of the first 10 and last 10 measurements (2, 3 and 4$)$, differences of $0.5,0.9$ and $1.9 \mathrm{ISQ}$ respectively were observed.

\section{DISCUSSION}

The results showed high statistical correlation between the reproducibility and repeatability measurements tested by Osstel ${ }^{\circledR}$ and are in agreement with other authors of clinical studies with similar objectives (Herrero-Climent et al., 2012; Nedir et al., 2004). However, the assay showed ISQ values with a decreasing tendency when the first and the last measurements recorded for the repeatability test were compared. In the most critical case (SmartPeg 4), ISQ reduction was 4 , and the clinical significance of this decrease depended on which the correlation between micromovements and ISQ values were lineal or 
BRIZUELA-VELASCO, A.; FERNÁNDEZ-GONZÁLEZ, F. J.; MARTíN-BLANCO, N.; CHÁVARRI-PRADO, D.; CHENTO-VALIENTE, Y.; DEHESA-IBARRA, B. \& VEGA, J. A. Accuracy of resonance frequency analysis by third generation Osstell囚. Int. J. Odontostomat., 9(3):489-492, 2015.

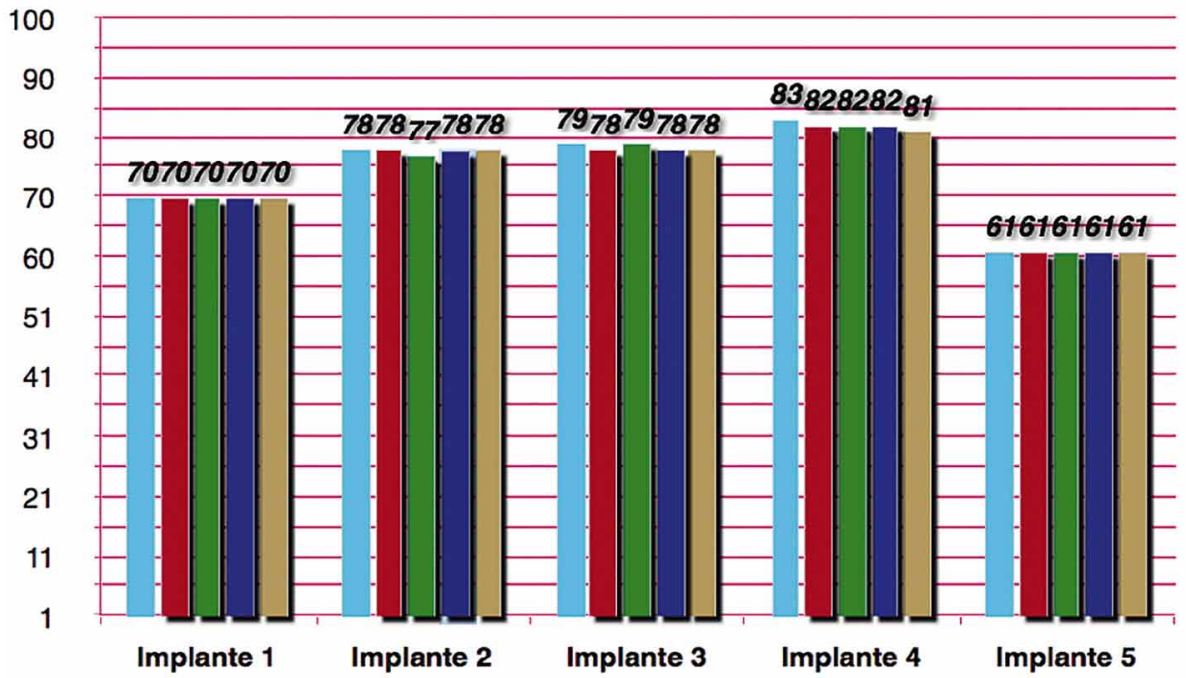

Fig. 3.Reproducibility tests on the five implants.

Table I. Repeatability test on five implants.

\begin{tabular}{cccccc}
\hline $\mathbf{n}$ & Implant & Implant & Implant & Implant & Implant \\
\hline 1 & 71 & 78 & 77 & 80 & 61 \\
2 & 71 & 78 & 77 & 80 & 61 \\
3 & 71 & 78 & 76 & 80 & 61 \\
4 & 70 & 78 & 76 & 80 & 61 \\
5 & 70 & 78 & 76 & 80 & 61 \\
6 & 70 & 78 & 77 & 80 & 61 \\
7 & 70 & 78 & 76 & 79 & 61 \\
8 & 70 & 78 & 76 & 79 & 61 \\
9 & 70 & 78 & 76 & 77 & 61 \\
10 & 70 & 77 & 76 & 77 & 61 \\
11 & 70 & 78 & 76 & 77 & 61 \\
12 & 70 & 78 & 75 & 78 & 61 \\
13 & 70 & 78 & 75 & 78 & 61 \\
14 & 70 & 78 & 76 & 78 & 61 \\
15 & 70 & 77 & 76 & 77 & 61 \\
16 & 70 & 78 & 76 & 78 & 61 \\
17 & 70 & 78 & 75 & 77 & 61 \\
18 & 70 & 78 & 75 & 77 & 61 \\
19 & 70 & 76 & 75 & 77 & 61 \\
20 & 70 & 75 & 75 & 76 & 61 \\
\hline
\end{tabular}

The RFA by third-generation Osstell ${ }^{\circledR}$ is a test exponential. This trend could be explained when microscopically (Fig. 4), which would justify a higher oscillation. These events suggest that the accuracy of the method can be preserved by limiting the use of each SmartPeg.

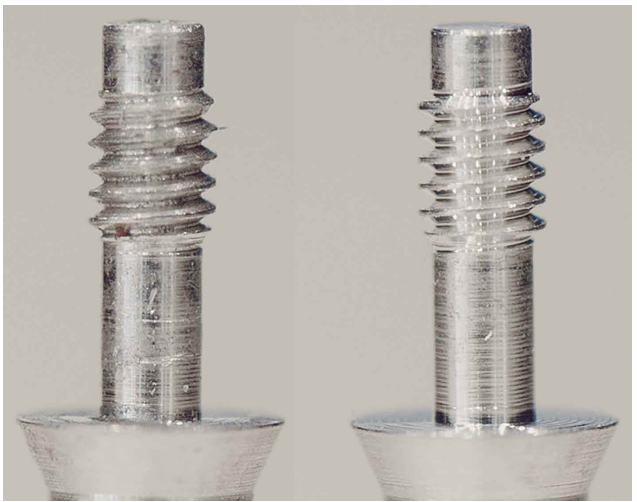

Fig. 4.Comparative between twenty SmartPeg uses and a new SmartPeg on its left. 
BRIZUELA-VELASCO, A.; FERNÁNDEZ-GONZÁLEZ, F. J.; MARTíN-BLANCO, N.; CHÁVARRI-PRADO, D.; CHENTOVALIENTE, Y.; DEHESA-IBARRA, B. \& VEGA, J. A. Precisión del análisis de frecuencia de resonancia mediante Osstell ${ }^{\circledR}$ de tercera generación. Int. J. Odontostomat., 9(3):489-492, 2015.

RESUMEN: El análisis de frecuencia de resonancia (AFR) por Osstel ${ }^{\circledR}$ se utiliza en la evaluación de la estabilidad primaria y secundaria del implante. El objetivo del presente estudio fue establecer la precisión del AFR mediante Osstell ${ }^{\odot}$, como método de prueba empleado en la determinación de la estabilidad implantaria. Se realizó un estudio experimental in vitro, en el que se colocaron implantes en una costilla de vaca y compararon diferentes mediciones del coeficiente de estabilidad del implante (ISQ) obtenidas sobre estos implantes con un mismo transductor SmartPeg (repetibilidad) o con diferentes SmartPegs (reproductibilidad). El análisis estadístico de los datos mostró una elevada correlación de los ISQ obtenidos en ambos ensayos, lo cual sugiere una reproductibilidad y repetibilidad elevada del análisis mediante Osstell.

PALABRAS CLAVE: Osstell, análisis de frecuencia de resonancia, estabilidad del implante, repetibilidad y reproducibilidad.

\section{REFERENCES}

Gapski, R.; Wang, H. L.; Mascarenhas, P. \& Lang, N. P. Critical review of immediate implant loading. Clin. Oral Implants Res., 14(5):515-27, 2003.

Herrero-Climent, M.; Albertini, M.; Rios-Santos, J. V.; LázaroCalvo, P.; Fernández-Palacín, A. \& Bullon, P. Resonance frequency analysis-reliability in third generation instruments: Osstell mentor®. Med. Oral Patol. Oral Cir. Bucal, 17(5):e801-6, 2012.

Nedir, R.; Bischof, M.; Szmukler-Moncler, S.; Bernard, J. P. \& Samson, J. Predicting osseointegration by means of implant primary stability. Clin. Oral Implants Res., 15(5):520-8, 2004

Pagliani, L.; Sennerby, L.; Petersson, A.; Verrocchi, D.; Volpe, S. \& Andersson, P. The relationship between resonance frequency analysis (RFA) and lateral displacement of dental implants: an in vitro study. J. Oral Rehabil., 40(3):221-7, 2013.

Tricio, J.; van Steenberghe, D.; Rosenberg, D. \& Duchateau, L. Implant stability related to insertion torque force and bone density: An in vitro study. J. Prosthet. Dent., 74(6):608-12, 1995
Correspondence to:

Dr. Felipe J. Fernández-González

Professor of the Graduate of Orthodontics and Dentofacial Orthopedics

Department of Orthodontics

Dentistry School

University of Oviedo

Asturias

SPAIN

Email: fjvazquezvega@gmail.com

Received: 15-10-2014

Accepted: 10-10-2015 